\title{
THE PRINCIPLES OF ISLAMIC GUIDANCE AND COUNSELING IN MENTAL DEVELOPMENT ACTIVITIES IN THE STATE POLICE SCHOOL OF THE NORTH SUMATERA REGIONAL POLICE
}

\author{
Siti Asiyah ${ }^{1}$, Saipul Achyar ${ }^{2}$, Abdurrahman $^{3}$ \\ ${ }^{1,2,3}$ State Islamic Univesity of North Sumatra, Indonesia \\ Email:Sitibata71@gmail.com
}

\begin{abstract}
This research was conducted preceded by the desire of the researcher himself to explore the principles of counseling guidance at the State Police School (SPN) of the North Sumatra Regional Police. This study aims to determine the role of Guidance and Counseling in Mental Development activities at the North Sumatra Regional Police State Police School. The method used in writing this research was qualitative in a case study approach. The research data were collected through interviews and observations. Furthermore, the data were analyzed using thematic analysis techniques. The results showed that in terms of motivating the State Police School students to apply the principles of Islamic guidance and counseling, so as to achieve good learning outcomes and mentally healthy. This can be seen from the success of these students in completing the learning process. Furthermore, the mental assessment of students in terms of problems that did students have restrictions and obligations. If you violated the prohibition, you will be mentally reduced. Personality mentality reflected in student learning outcomes, so if the student's mentality was good then the performance will be good.
\end{abstract}

Keywords: $\quad$ Guidance; Health; Counseling; Mental

\section{INTRODUCTION}

Education is a conscious and planned effort in the process of mentoring and learning for individuals to develop into independent, responsible, creative, knowledgeable, healthy and noble human beings (Suyadi 2013). In addition, education is a human effort to foster their personality according to the values in their society and culture (Hamalik, 2004; Dewey, 2003). Thus, however simple the civilization of a society is, an educational process occurs or takes place. That's why it is often stated that education has existed throughout human civilization.

Education is essentially a human effort to preserve his life. In Article 39 of Law No. 20 of 2003 concerning the National Education System, which states that educators are professionals who are tasked with planning and implementing the learning process, assessing learning outcomes, conducting guidance and training, and conducting research and community service. As part of education, guidance is the process of providing assistance to people continuously and systematically by mentors so that individuals or groups of individuals become independent individuals.

The term guidance and counseling as stated in Winkel and Hastuti (2012) is a translation of the words Guidance and Counseling. Basically guidance and 
counseling is an effort to provide assistance to students so that they can understand themselves so that they are able to direct themselves and act properly in accordance with their mental development. . This effort is carried out systematically and continuously (Azet, 2012; Prayetno \& Emti (2009). Meanwhile, according to the government no 28/1990 on Basic Education, article 25 paragraph 1. Guidance is assistance provided to students in an effort to find personal, know the environment and planning for the future".

According to Dunsmoor and Miller (1949), guidance and counseling aims to help individuals to understand and make extensive use of the educational, position, and personal opportunities they have or can develop, and as a form of systematic assistance through which students are assisted to obtain adjustment of both his school and personal life

The National Police School (SPN) POLDA SUMUT has implemented the Counseling Guidance program in the Counseling Guidance Principle according to applicable programs and procedures. In selecting the Counseling Guidance teacher, it also has several requirements, namely that it must have an appropriate scientific background, in other words, the teachers who are in charge of providing guidance and counseling to students have a scientific background of guidance and counseling. One of the programs for providing guidance and counseling is the provision of Islamic guidance and counseling.

Because of the importance of this Islamic guidance and counseling process, we conducted a study aimed at knowing the role of Islamic Guidance and
Counseling in Mental Development activities at the North Sumatra Regional Police State Police School.

\section{METHOD}

The method used in this research was qualitative research method. While the research approach used was a case study approach. Qualitative method is a research method in which the research process is based on a way to investigate a social phenomenon and a human problem (Creswel, 2012; Cohen, Manion \& Morrison, 2007). The case study approach is taken because case studies were a qualitative research approach to understanding individuals that is carried out integratively and comprehensively in order to obtain a deep understanding of the individual (Heigham \& Croker, 2009; Gall, Gall \& Borg, 2007).

This research conducted at the State Police School (SPN) Polda North Sumatra. Participants in this study were selected using a purposeful sampling technique (Creswell, 2012; Fraenkel, \& Wallen, 2012). Participants in this study were the coordinator of guidance and counseling activities, teachers and students who were given Islamic counseling guidance.

To answer the formulation of research problems, the research data were obtained from interviews and observations. Interviews conducted with the coordinator of the Islamic Counseling Guidance program, teachers and students to find out how the impact of the implementation of Islamic Counseling Guidance on student performance, while observations were made to observe the phenomena that occurred during the implementation 
process of the Islamic counseling guidance program.

Data obtained from observations and interviews analyzed using thematic analysis (Heigham \& Croker, 2009). The thematic analysis stage started from reducing the data that has been obtained, then collecting data codes that were similar and concluding the coding data that has been carried out in the form of a theme which will then be described in a narrative.

\section{RESULT}

Based on the results of interviews and observations, the results of data analysis obtained two main themes which will then be described in a narrative manner. The two themes are: 1) Principles of Islamic Counseling Guidance at the North Sumatra Police State Police School (SPN) and 2) Reflection on the implementation of Islamic Counseling Guidance at the North Sumatra Police State Police School (SPN).

\section{Principles of Islamic Counseling Guidance in State Police Schools (SPN) POLDA SUMUT}

Based on the results of interviews of researchers with the head of teaching (Koogadik) related to the guidance and counseling process every day at the State Police School (SPN) POLDA SUMUT, he said

"Counseling activities are carried out in congregational prayer activities for those who adhere to the Islamic religion. After completing the prayer service, there is guidance or direction such as lectures and other motivational words." (Personal Communication, 2020)

The results of this interview were also supported by observations where the provision of guidance and counseling in congregational prayer activities was a program that originated from the initiative of religious teachers and teachers of Guidance and Counseling and has been carried out regularly at SPN Polda SUMUT. As explained by the SPN Polda Sumut Train above, the objective of implementing this congregational prayer program is to increase the love of worship for students.

With the goal to be achieved in a counseling guidance principle, it was necessary to look at the role of guidance and counseling teachers properly. To find out this, the researcher conducted an interview with the National Police School Train (SPN) POLDA SUMUT regarding learning motivation in the process of Guidance and Counseling Principles, information can be obtained as follows:

In the Principles of Guidance and Counseling at the State Police School (SPN), POLDA SUMUT is very closely related to the learning adopted at the State Police School (SPN) POLDA SUMUT. Because the cooperation between all parties must run properly and coordinate with each other. We also add the Counseling Guidance subject at the National Police School (SPN) POLDA SUMUT to class 4. The lesson hours for the formation of cultural character every week to shape the character of these students to be better. This is done to synchronize subject teacher reports to BK teachers (student caregivers) in helping solve existing problems, as well as assisting students in increasing enthusiasm for learning and also not being separated from the Deputy Principal of the National Police School (SPN) POLDA SUMUT for Student Affairs. This is not limited by the 
National Police School (SPN) POLDA SUMUT and does not interfere with the learning process in the classroom while still in reason and wisdom (Personal Communication, 2020)

Based on the explanation presented above, we could understand that in principle, Guidance and Counseling at the State Police School (SPN) POLDA SUMUT has a significant positive impact on students. Providing guidance and counseling means to support the optimal development of students. In principle, Counseling gave priority to the development of communication and socialization skills. The ability to communicate and socialize is very important for students so that students can be active and can communicate and socialize well.

The implementation of the Counseling Guidance has had a positive effect on students. By cooperating with each other between class teachers, subject teachers and Guidance and Counseling teachers, students felt comfortable and calm because they were paid attention. This is an evident from the results of interviews with Guidance and Counseling teachers about the steps in implementing Islamic Counseling Guidance which was oriented to increase student learning motivation as follows:

The steps in the Counseling Guidance Principle need to be done, 1) Determine the goals to be achieved, 2) Analyze the sources and constraints to be faced, 3) Analyze the needs needed, 4) Determine more goals. specific and measurable so that what you want is achieved, 5) Determining what priorities should come first, 5) Determining strategies and activities related to specific goals,
6) Conducting an evaluation of planning, and finally , 7) Making some changes that are necessary for improvement and increasing learning motivation. (Personal Communication, 2020).

Based on the description above, it can be understood that in the implementation of Counseling Guidance there are many things that need attention. Because, the implication is direct to what students feel. To find out how students feel about the Counseling Guidance process at the North Sumatra Police State Police School (SPN), researchers conducted an interview with one of the students of the North Sumatra Police State Police School (SPN). Based on the results of interviews with students of the State Police School (SPN) POLDA SUMUT, the following information was obtained:

In my opinion, the Principles of Guidance and Counseling in the National Police School (SPN) POLDA SUMUT, are always actively implemented. Because there are so many different characters of students because students come from various regions in North Sumatra, even outside of North Sumatra. And also a lot of support received from various parties. This activity really helped me to express my opinion. After participating in this counseling activity, my classmates and I who participated in this activity can increase enthusiasm for learning. (Personal Communication, 2020)

Interview results are also supported by observations. From the results of the analysis of the observational data, it can be concluded that the role of the Guidance and Counseling teacher in implementing Guidance and Counseling is an effort to 
provide guidance and direction to students who experience difficulties at the National Police School (SPN) POLDA SUMUT The process of implementing activities is directed to help students understand themselves, increase their motivation to learn, express their own opinions, and respect each other's opinions.

At the beginning of the activity, the class dynamics were not fully in accordance with the expectations of the researchers. This is because students come from different cultural backgrounds. After carrying out the activities of Islamic Guidance and Counseling, there is a change in students. Class dynamics slowly occur in each class that is formed, ranging from discipline, courage to express opinions while guidance is taking place to exchange opinions with other class members.

Based on the results of field observations and interviews conducted by researchers with $\mathrm{BK}$ teachers at the National Police School (SPN) of the North Sumatra Police, it was found that the components in the implementation of the Counseling Guidance activities carried out at the State Police School (SPN) POLDA SUMUT Hinai District Langkat are class leader and class members.

According to the data obtained by the researcher, the class leader in this case has an important role in bringing members to an atmosphere that supported the achievement of the objectives of the Counseling Guidance. In this case, as class leaders were BK teachers who knew the role of class leaders and as class members were students of the North Sumatra Police State Police School (SPN).
Reflection on the implementation of Islamic Counseling Guidance at the North Sumatra Police State Police School (SPN)

Based on the interview with the counseling teacher about reflection after the implementation of the Counseling Guidance activities are as follows:

After all the planning and implementation of the Counseling Guidance Principle has been carried out, it can be seen that the result of the implementation of the Counseling Guidance in SPN schools is that students become active and have good grades in general subjects. Next thing to think about is to arrange a followup in the future. After the Counseling Guidance at the State Police School (SPN) POLDA SUMUT was carried out well.

Based on the above interview, it can be understood that, after all stages of the individual Islamic counseling process have been carried out, then there is a follow-up to the implementation of the Islamic Counseling Guidance. The aim is to measure the extent to which the principles of Islamic counseling have been carried out and the level of success that must be seen.

Based on the results of observations made regarding the results obtained after the holding of Islamic counseling guidance activities at the State Police School (SPN) POLDA SUMUT, it can be seen that the student response is very good. This can be seen from the attitude of students who want to provide answers when the counseling teacher asked questions and when the Islamic Counseling Guidance process is carried out the students were quite active in participating in the ongoing teaching and 
learning process. At first, students were a little embarrassed to express or convey the opinions they wanted to express for fear that their answers were wrong. Then the Guidance and Counseling teacher and subject teacher gave encouragement to students that there are no wrong or right answers. After that, students began to actively respond to what was asked by other classmates.

Furthermore, based on the results of observations, information was obtained that students were active in participating in the Counseling Guidance activities. In the process of implementing Islamic Counseling Guidance, students always provide feedback on the feedback given by their teacher. when students feel they do not know what the Guidance and Counseling teacher has expressed, students have the courage to ask their teacher. In addition, the students showed body gestures that looked very enthusiastic in following all the stages in the Islamic Counseling Guidance process.

Furthermore, from the observations it can be seen that after the counseling teacher conducts counseling, students take changes in terms of communication, namely in terms of issuing opinions, students begin to give their contribution which was not previously predicted by the guidance and counseling teacher at the beginning of the implementation of the Islamic Counseling Guidance. At first the teacher thought the students would find it difficult to follow the stages of the process, but in practice the students gave their opinion on understanding the material given.

From the observation results also obtained information that the Counseling Guidance implementation technique used is class discussion and home room. Home room is a technique of Counseling Guidance Principles which is done by creating a family situation (an atmosphere like at home).

From the explanation above, it can be concluded that the implementation of the stages of the Islamic Counseling Guidance process at the State Police School (SPN) POLDA SUMUT has been going well. As for Islamic counseling guidance efforts in increasing student motivation at the State Police School (SPN) POLDA SUMUT carried out by applying the Islamic concept, namely inviting all students to perform congregational prayers, in this case performing Dhuha prayers and zhuhur prayers, performing prayer rituals before carrying out activities academic at school and class. According to the information provided by the Counseling Guidance teacher (BK), so far the counseling guidance program carried out at the State Police School (SPN) POLDA SUMUT especially for all students has been very effective in increasing student learning motivation.

\section{DISCUSSION}

Based on the results of data collection, both from observation and from interviews, it can be concluded that the implementation of the stages of the process of Islamic Counseling Principles in the State Police School (SPN) POLDA SUMUT has been going well. The efforts of Islamic counseling guidance in increasing student motivation in the North Sumatra Police State Police School (SPN) are carried out by applying the Islamic concept, which is inviting all students to perform congregational prayers in this case 
do dhuha prayers and dzhuhur prayers, perform prayer rituals before carrying out activities academic at school and class. According to the information provided by the Counseling Guidance (BK) teacher that so far the counseling guidance program conducted at the SPN Hinai school, especially for students, has been very effective in increasing student learning motivation.

The process of implementing the counseling guidance program is carried out by the Counseling Guidance teacher with a police education background, not a counseling education background, so that the learning materials and methods provided to students of SPN Hinai Langkat Regency by the teacher are only based on information obtained from package books and from sources that can be accessed on the internet. The sources he summarized himself (Own Initiative). In addition, the materials and implementation methods were also obtained by following the training process and workshop that the teacher participated in. However, it does not reduce the ability and quality of the teacher to apply the theory and methods of learning counseling guidance to students of SPN Hinai, Langkat Regency. This can be seen from the success of these students in completing the learning process at the SPN Hinai school, Langkat Regency.

The inhibiting factors in carrying out Islamic counseling guidance efforts in increasing learning motivation of the North Sumatra Police State Police School (SPN) are: 1) Background of the Counseling Guidance Teacher who is not from the Counseling Guidance Education; 2) Parents who are not open to student problems requiring counseling; 3) Islamic counseling guidance learning methods and materials that are not in detail (do not have specific standards as a measure of the success of a theory) and 4) less supportive facilities and infrastructure.

\section{CONCLUSION}

Based on the results of the above research, it can be concluded that the role of Guidance and Counseling in Mental Development activities at the State Police School of the North Sumatra Regional Police is carried out by means of physical guidance. Parenting plays an important role in carrying out counseling guidance to students. With the process of Islamic counseling guidance can give birth to mentally healthy students. The mental assessment of students in terms of student responses has restrictions and obligations. If he violates the prohibition, his mental assessment is reduced. Mental personality has been reflected in student learning outcomes, so if the student's mentality is good then the performance will be good.

\section{REFERENCES}

Azzet, A.M. (2013). Bimbingan \& Konseling di Sekolah. Jogjakarta: Ar-Ruzz Media.

Cohen, L., Manion, L., \& Morrison, K. (2007). Research methods in education.London: Routledge Flamer

Creswell, J. W. (2012). Educational research: Planning, conducting, and evaluating quantitative and qualitative research (4th ed.). Boston, MA: Pearson

Dewey, J. (2003). Dasar-Dasar Ilmu Pendidikan. Jakarta: PT Raja Grafindo Persada

Dunsmoor, C.D., \& Miller, L.M. (1949). Principles and Methods of Guidance for Teachers.Scranton, Penna: International Textbook Co. 
Fraenkel, J.R.\& Wallen, N.E. (2012). How to design and evaluate research in education. San Fransisco, CA: Mc Graw Hill

Gall, M., Gall, J., \& Borg, R. (2007). Educational research: An introduction (8th ed.). New York, NY: Pearson Education

Hamalik, O. (2004). Perkembangan Peserta Didik. Jakarta: PT Rineka Cipta

Heigham, J.,\& Croker, R. (2009). Qualitative research in applied Linguistics: $\quad A$ practical introduction. UK: Palgrave Macmillan

Prayetno dan Emti, E. (2009). Dasardasar Bimbingan dan Konseling. Jakarta: Rieneka Cipta.

Suyadi. (2013). Strategi Pembelajaran Pendidikan Karakter, Bandung: Remaja Rosdakarya.

Undang-undang No. 20 Tahun 2003 tentang Sistem Pendidikan Nasional.

Winkel, W.S dan Hastuti, Sri. 2012. Bimbingan dan Konseling di Institusi Pendidikan, Yogyakarta: Media Abadi. 